\title{
Schottarum (Schismatoglottideae: Araceae) substantiated based on combined nuclear and plastid DNA sequences
}

\author{
Shook Ling Low • Sin Yeng Wong • \\ Peter C. Boyce
}

Received: 26 March 2013/ Accepted: 15 August 2013

(C) Springer-Verlag Wien 2013

\begin{abstract}
Recent studies on Schismatoglottideae have resulted in the recognition of four new monophyletic genera, the resurrection of two additional genera following clarification of their monophyly, and the publication of many taxonomically novel species. However, generic boundaries among some parts of Schismatoglottideae remain unclear owing to several reasons: (1) more taxa are being revealed through our on-going fieldwork, now expanded to previously unsampled localities on Borneo; (2) established occurrence of a high level of homoplasies among the morphological characteristics hitherto used to delimitate genera; and (3) gene regions used in previous studies contradicted some of current taxonomic placements. Among the unsolved groups from previous studies a clade comprising Schismatoglottis sarikeensis and S. josefii needs further investigation. Therefore, phylogenetic analyses were carried out to investigate the position of these two species using the nuclear region, internal transcribed spacer and combined plastid regions: $\operatorname{trn} \mathrm{L}$ intron and $\operatorname{trn} \mathrm{L}-$ $\mathrm{F}$ intergenic spacer, coding $m a t \mathrm{~K}+$ partial $3^{\prime} \operatorname{trn} \mathrm{K}$, intergenic spacer $t r n \mathrm{H}-p s b \mathrm{~A}$. A total of 23 accessions representing 16 taxa of Schismatoglottideae and Philonotieae were included in the study. Phylogenetic analyses of a total 4,658 bp combined dataset using parsimony, maximum likelihood, and Bayesian methods revealed that $S$. sarikeensis and S. josefii do not belong to Schismatoglottis, and
\end{abstract}

S. L. Low · S. Y. Wong $(\square)$

Department of Plant Science and Environmental Ecology,

Faculty of Resource Science and Technology, Universiti

Malaysia Sarawak, 94300 Kota Samarahan, Malaysia

e-mail: sywong@frst.unimas.my

P. C. Boyce

Pusat Pengajian Sains Kajihayat (School of Biological Sciences),

Universiti Sains Malaysia, 11800 Pulau Pinang, Malaysia therefore are transferred to Schottarum ( $\equiv$ Hottarum sarikeense $\equiv$ Schismatoglottis sarikeense). Flowering mechanism, pollination strategy, and fruitset of $S$. sarikeense are also presented in the paper.

Keywords Borneo - Flowering mechanism · Phylogeny · Pollination · Taxonomy

\section{Introduction}

Previous work by Wong et al. (2010) established the Schismatoglottid Alliance comprising three tribes, Philonotieae, Cryptocoryneae, and Schismatoglottideae. Schismatoglottideae comprises one large genus, Schismatoglottis Zoll. \& Moritzi and ten small genera (Wong 2013). Schismatoglottis sensu Hay and Yuzammi (2000) is now trimmed by removal of the Neotropical Schismatoglottis species, the Rupestris Group (Hay and Yuzammi 2000), and S. longifolia Ridl. into three separate genera, respectively: Philonotion Schott (Wong et al. 2010; Cusimano et al. 2011), Apoballis Schott, and Hestia (Wong and Boyce 2010). In addition to these taxa, a group of species are shown to be separated from the main clade, Schismatoglottis, and are recognised as Supra Lupar Divide clade (Low et al. 2011; Wong 2013). The Lupar Divide sits on the Lupar River at Sri Aman Division, Sarawak (Malaysian Borneo). The clade is particularly interesting in that it is centred in northern central Sarawak, north of the Lupar Divide, and appears to represent an autochthonous radiation point for evolutionary activity isolated from the major tribal radiations in south western Sarawak (Wong 2013). The Supra Lupar Divide clade consists of Schismatoglottis sarikeensis (Bogner \& M. Hotta) A. Hay \& Bogner, $S$. josefii A. Hay, six novel species of 'Schismatoglottis' from Kapit Division, and Phymatarum borneense M. Hotta. 
Schismatoglottis sarikeensis was initially described as a species of the genus Hottarum (Hottarum sarikeense Bogner \& Hotta 1983) based on a basal placentation and seeds without a micropylar appendage, although in many respects its position in Hottarum is clearly anomalous having pendent infructescences without splash-cup persistent lower spathes. Bogner and Hay (in Hay and Yuzammi 2000) dismantled Hottarum (with the type, H. truncatum transferred to Piptospatha N.E.Br.), and moved H. sarikeense into the Multiflora group of Schismatoglottis on the basis of the constricted spathe and free ligular leaf sheath, this despite basal placentation being clearly unique in Schismatoglottis. Low et al. (2011) subsequently showed $S$. sarikeensis to not be related to Hottarum truncatum (the type species for now monospecific Hottarum) based on the nuclear Internal Transcribed Spacer (ITS) region nor to belong in Schismatoglottis, Piptospatha, or Bakoa P. C. Boyce \& S. Y. Wong, where the genera and the species of former Hottarum (sense Mayo et al. 1997) are now placed. The aim of this study is to clarify the placement of these anomalous taxa in Schismatoglottideae using molecular phylogenetic results based on the nuclear ITS region and three plastid regions $\operatorname{trn} \mathrm{L}$ intron and $\operatorname{trn} \mathrm{L}-\mathrm{F}$ intergenic spacer (trnL-F), coding mat $\mathrm{K}+$ partial $3^{\prime} \operatorname{trn\mathrm {K}}$ $(m a t \mathrm{~K})$, intergenic spacer $t r n \mathrm{H}-p s b \mathrm{~A}$. Flowering mechanism, pollination strategy, and fruitset of S. sarikeensis are also discussed.

\section{Materials and methods}

Taxa sampling

A total of 22 accessions representing 15 taxa of Schismatoglottideae were included as ingroup. Thirty sequences were newly generated and submitted to GenBank with the accession numbers from KC454001 to KC454030. These sequences were combined with sequences from previous studies (Wong et al. 2010; Low et al. 2011; Ting et al. 2012; Wong 2013). Philonotion americanum (A. M. E. Jonker \& Jonker) S. Y. Wong \& P. C. Boyce was chosen as outgroup for the study. Voucher information and GenBank accession numbers are provided in "Appendix".

DNA extraction, PCR amplification and sequencing

Total genomic DNA was extracted from either fresh or silica-gel dried leaf tissues using a modified version of the 2X CTAB protocol (Doyle and Doyle 1987) with the addition of Polyvinylpyrrolidone (PVP; Wong et al. 2010). The nuclear ITS region and three plastid gene regions: $t r n \mathrm{~L}-\mathrm{F}, m a t \mathrm{~K}$, and $t r n \mathrm{H}-p s b \mathrm{~A}$, were targeted for polymerase chain reaction (PCR) amplification. Primers used are
Table 1 PCR and sequencing primers used for this study

\begin{tabular}{|c|c|c|}
\hline Primers & Sequences of the primers & References \\
\hline \multicolumn{3}{|l|}{ ITS $1 \mathrm{~F}$} \\
\hline $1 \mathrm{R}$ & $\begin{array}{l}\text { 5'-GAGGAAGGAGAAGTCGTA } \\
\text { ACAAGG-3' }\end{array}$ & White et al. (1990) \\
\hline $3 \mathrm{~F}$ & $\begin{array}{l}\text { 5'-ACTTGCGTTCAAAGATTC } \\
\text { GATGG-3' }\end{array}$ & White et al. (1990) \\
\hline \multirow[t]{2}{*}{$4 \mathrm{R}$} & $\begin{array}{l}5^{\prime} \text {-GCATCGATGAAGAAC } \\
\text { GTAGC-3' }\end{array}$ & White et al. (1990) \\
\hline & $\begin{array}{l}5^{\prime} \text {-TCCTCCGCTTATTGA } \\
\text { TATGC- } 3^{\prime}\end{array}$ & White et al. (1990) \\
\hline \multicolumn{3}{|c|}{$\operatorname{trn} \mathrm{L}-t r n \mathrm{~L}-\mathrm{F}$} \\
\hline $\mathrm{c}$ & $\begin{array}{l}\text { 5'-CGAAATCGGTAGACGC } \\
\text { TACG-3' }\end{array}$ & Taberlet et al. (1991) \\
\hline $\mathrm{d}$ & $\begin{array}{l}5^{\prime} \text {-GGGGATAGAGGGACT } \\
\text { TGAAC-3' }\end{array}$ & Taberlet et al. (1991) \\
\hline $\mathrm{e}$ & $\begin{array}{l}5^{\prime} \text {-GGTTCAAGTCCCTCT } \\
\text { ATCCC-3' }\end{array}$ & Taberlet et al. (1991) \\
\hline $\mathrm{f}$ & $\begin{array}{l}\text { 5'-ATTTGAACTGGTGACAC } \\
\text { GAG-3' }\end{array}$ & Taberlet et al. (1991) \\
\hline \multicolumn{3}{|l|}{$\operatorname{mat} \mathrm{K}$} \\
\hline $19 \mathrm{~F}$ & $\begin{array}{l}\text { 5'-CGTTCTGACCATATTG } \\
\text { CACTATG-3' }\end{array}$ & Gravendeel et al. (2001) \\
\hline $2 \mathrm{R}$ & $\begin{array}{l}\text { 5'-AACTAGTCGGATGG } \\
\text { AGTAG-3' }\end{array}$ & Steele and Vilgalys (1994) \\
\hline $390 \mathrm{~F}$ & $\begin{array}{l}\text { 5'-CGATCTATTCATTCAA } \\
\text { TATTTC-3' }\end{array}$ & Cuénoud et al. (2002) \\
\hline $1326 \mathrm{R}$ & $\begin{array}{l}\text { 5'-TCTAGCACACGAAAGT } \\
\text { CGAAGT-3' }\end{array}$ & Cuénoud et al. (2002) \\
\hline \multicolumn{3}{|c|}{ 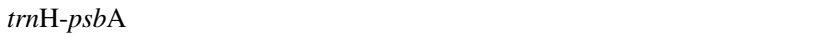 } \\
\hline $\operatorname{trn} \mathrm{H}$ & $\begin{array}{l}\text { 5'-CGCGCATGGTGGATTCA } \\
\text { CAATCC-3' }\end{array}$ & Tate and Simpson (2003) \\
\hline$p s b \mathrm{~A}$ & $\begin{array}{l}\text { 5'-GTTATGCATGAACGTA }^{\prime} \\
\text { ATGCTC- } 3^{\prime}\end{array}$ & Sang et al. (1997) \\
\hline
\end{tabular}

listed in Table 1. PCR amplification was done according to Low et al. (2011). The PCR products were visualised on 1.5 or $2.0 \%$ agarose gels, and purified using a PCR purification kit (Fermentas, Vilnius, Lithuania). Purified products were viewed again using a $1 \%$ agarose gel, and if a single clear band was present the products were sent for sequencing to First BASE Laboratories Sdn. Bhd., Selangor, Malaysia. Sequencing reactions were carried out using the same primer pairs during PCR amplification and the ABI PRISM BigDye ${ }^{\circledR}$ Terminator Version 3.0 Cycle Sequencing Kit on an $\mathrm{ABI}^{\circledR} 377$ DNA automated sequencer (Applied Biosystem, Foster City, CA, USA).

Sequence alignment and phylogenetic analyses

Newly generated sequences were assembled using BioEdit version 5.0.6 (Hall 1999) and manually adjusted. These sequences were combined and aligned with sequences from Wong et al. (2010), Low et al. (2011), Ting et al. (2012), and Wong (2013). Indels were treated as missing data. 
Phylogenetic analyses were performed with PAUP $* 4.0 \mathrm{~b} 10$ (Swofford 2002) for maximum parsimony (MP) reconstruction with all characters equally weighted. The most parsimonious trees were obtained with heuristic searches of 1,000 replicates with random stepwise sequences addition, tree bisection-reconnection (TBR) branch swapping, collapse of zero-length branches, with the multiple-tree option in effect, and saving up to 10,000 trees from each random sequence addition.

The most suitable nucleotide substitution model for each of the gene regions was selected in jModeltest ver. 0.1.1 (Posada 2008) using Akaike information criterion (AIC; Akaike 1974). The jModelTest identified that the Transversion Model plus Gamma (TVM+G) as best fit for matK, and $t r n \mathrm{~L}-t r n \mathrm{~L}-\mathrm{F}$. General Time Reversible plus Gamma $(\mathrm{GTR}+\mathrm{G})$ and Kimura 3-parameter $(\mathrm{TPM} 1 \mathrm{uf}+\mathrm{G})$ were selected as best fit substitution model for $t r n \mathrm{H}-p s b \mathrm{~A}$ region and ITS region, respectively. Maximum likelihood (ML) analyses were carried out using RAxML 7.2.6 (Stamatakis et al. 2008). ML bootstrap values were obtained by running 10,000 replicates. Bayesian phylogenetic analyses were performed with MrBayes ver. 3.1.2 (Huelsenbeck and Ronquist 2001). Markov chain Monte Carlo (MCMC) was repeated twice to assure parameter convergence. The MCMC algorithm was run for 2,000,000 generations with one cold and three heated chains, starting from random trees and sampling one out of every 100 generations. Convergence was assessed by using the standard deviation of split frequencies as convergence index with values $<0.005$ interpreted as indicating good convergence. The first $10 \%$ of trees were discarded as burn-in. Remaining trees were used to construct $50 \%$ majority rule consensus trees. In interpreting phylogenetic confidence, bootstrap support: $50-74 \%$ represents weak support, 75-84\% moderate support, and 85-100\% strong support with a posterior probability $(\mathrm{PP})$ of 0.97 or higher.

Methodology on flowering mechanism, pollination observations, and fruitset

Initial observations of $S$. sarikeensis were carried out by the second and third authors in April and December, 2005 and May 2008. Further observations on the flowering mechanism, pollination and fruitset of $S$. sarikeensis were carried out by first author from 24th January and 5th February 2010 at Sungai Lepong, Sebangkoi Recreational Park, Sarikei Division, Sarawak, Malaysia (01. 57N, 111. 31E). The population of $S$. sarikeensis grows on shales. Most of the plants remained on the upper part of the demarcation line for the flood plain; plants were occasionally submerged in water during heavy rainfalls.

Ten inflorescences of $S$. sarikeensis were observed. The type of insect visitors (identified to at least family level) and their behaviour were documented. To determine the attractant factor (odour vs colour) the spathe of five preanthesis inflorescences were removed, the spadices were kept intact and each covered with a plastic cover. Fruitset was defined as total fruits per infructescence over total pistillate flowers per inflorescence and used as measure of the effectiveness of the pollinators. A total of 50 replicates were sampled. All images were taken using an Olympus E-300 digital camera. All inflorescences, infructescences and insect visitors were preserved in $70 \%$ ethanol and deposited at Sarawak Forestry Herbarium (SAR).

\section{Results}

Matrix characteristics

Among the plastid regions, $t r n \mathrm{H}-p s b \mathrm{~A}$ is the most variable region but comprises high repeats of nucleotide AT from position of 452-726. The ITS region provides the most informative characters as compared to the plastid regions. Tree lengths, consistency indices $(\mathrm{CI})$ and retention indices (RI) for each region are shown in Table 2. The incongruence length difference (ILD; Farris et al. 1994) test exhibited congruity between the trnL-F and matK regions but both regions are not congruent $(P=0.01)$ with $t r n \mathrm{H}$ $p s b \mathrm{~A}$ and ITS regions. Therefore, the datasets were only combined for trnL-F and mat $\mathrm{K}$ regions.

Phylogenetic analyses

All branches of the trees generated from the region $\operatorname{trn} \mathrm{H}-$ $p s b \mathrm{~A}$ collapsed owing to no support values. Combined plastid regions, trn $\mathrm{L}-\mathrm{F}$ and $m a t \mathrm{~K}$, resulted in much improved resolution, however, support values were still poor. The Supra Lupar clade is supported but with the exclusion of both accessions of S. sarikeensis (Ar1605 and Ar2394). The placements of the other genera included, Aridarum, Bucephalandra, and Schismatoglottis do not fit their current taxonomic position. On the basis of these analyses, $t r n \mathrm{H}-\mathrm{psbA}, t r n \mathrm{~L}-\mathrm{F}$ and $m a t \mathrm{~K}$ are excluded from our further discussion.

Phylogenetic analyses of the ITS region produced a cladogram with better topology and improved support for crown clades (Fig. 1). The phylogeny presented included two more taxa, Bucephalandra motleyana (Ar2310) and Aridarum nicolsonii (Ar2098) as compared to the phylogeny presented in Low et al. (2011). The Supra Lupar Divide clade is separated into two sister clusters: three new species of 'Schismatoglottis' from Kapit, and Schottarum clade. Apart from Schismatoglottis 'petradoxa' which is yet to be formally described, the other two species have yet to flower. The Schottarum clade is strongly supported with 
Table 2 Sequence variation of the nuclear ribosomal internal transcribed spacer (ITS) and the plastid regions ( $\operatorname{trn} \mathrm{L}-\mathrm{F}$, $m a t \mathrm{~K}$ and $\operatorname{trn} \mathrm{H}-p s b \mathrm{~A})$ of the 23 taxa (Tribe Schismatoglottideae and Philonotieae) included in the study

\begin{tabular}{|c|c|c|c|c|}
\hline Region(s) & No. of aligned characters & No. $(\%)$ of variable/informative characters & Tree length & $\mathrm{CI} / \mathrm{RI}$ \\
\hline ITS & 889 & $185(20.81 \%) / 50(5.62 \%)$ & 294 & $0.88 / 0.75$ \\
\hline trnL-trnL-F & 1,156 & $76(6.57 \%) / 11(0.95 \%)$ & 96 & $0.94 / 0.77$ \\
\hline matK & 1,600 & $86(5.38 \%) / 23(1.44 \%)$ & 124 & $0.91 / 0.81$ \\
\hline$t r n \mathrm{H}-p s b \mathrm{~A}$ & 1,013 & $114(11.25 \%) / 31(3.06 \%)$ & 171 & $0.87 / 0.69$ \\
\hline
\end{tabular}

CI Consistency index, RI retention index

Fig. 1 Bayesian $50 \%$ majority rule consensus tree obtained using the nuclear internal transcribed spacer (ITS) region. Posterior probabilities $>0.80$ are shown above branches, bootstrap values $>60 \%$ (maximum parsimony and maximum likelihood) are shown below the branches

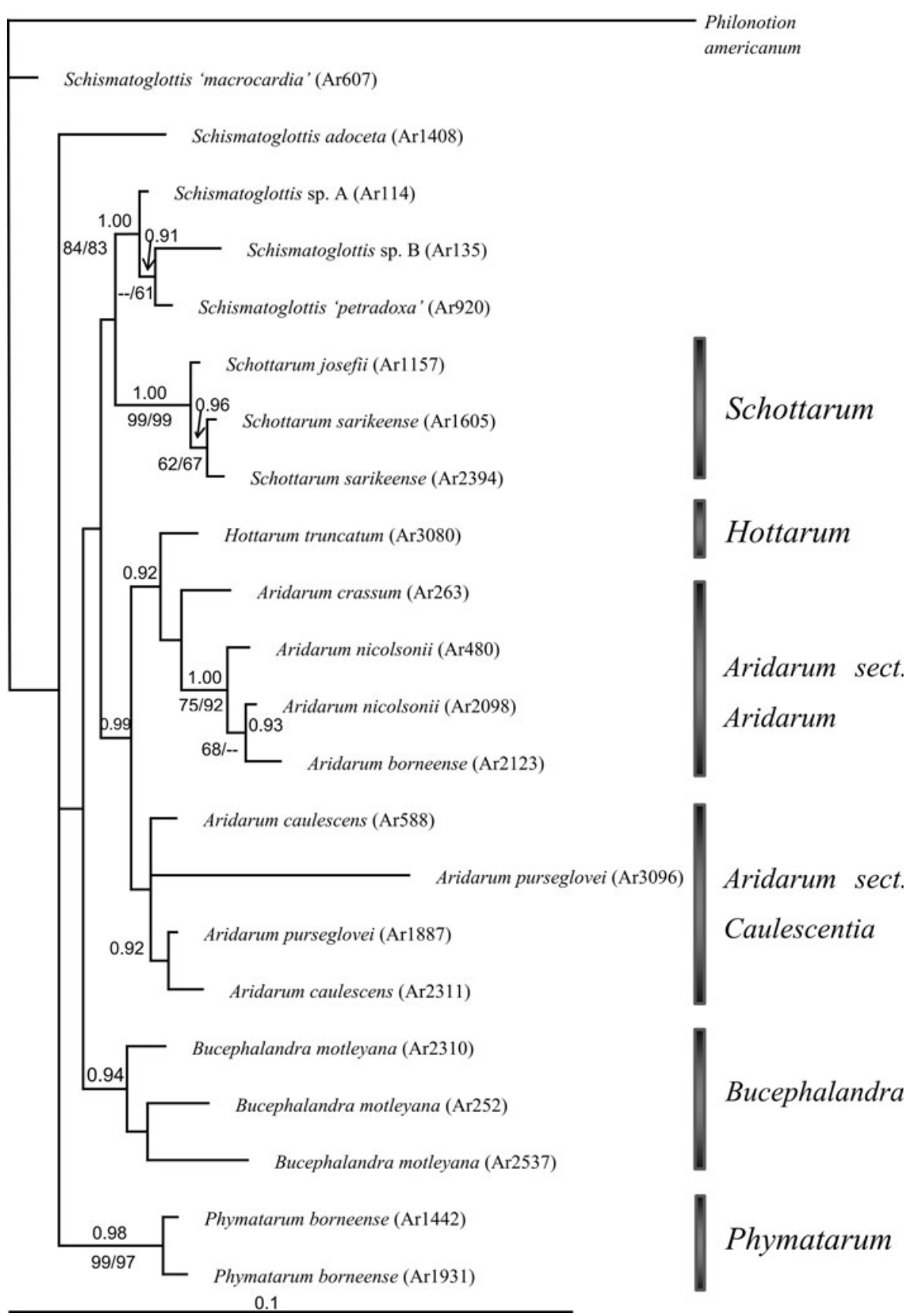


S. josefii grouped together with both accessions of $S$. sarikeensis (MP 99 \%, ML $99 \%$ and PP 1.00). H. truncatum is supported basally to Aridarum (PP 0.99). Aridarum is separated into two separate clades and this follows available taxonomic placements, section Aridarum and $\mathrm{Ca}$ ulescentia. Three accessions of $B$. motleyana and two accessions of $P$. borneense fell into a single clade, respectively, with moderate and strong support values, respectively (MP $99 \%$, ML $97 \%$ and PP 0.98).

\section{Discussion}

Taxonomic implications

Schismatoglottis sarikeensis and $S$. josefii do not belong in Schismatoglottis. There is an existing name, Schottarum P. C. Boyce \& S. Y. Wong, which was reduced as synonym to Schismatoglottis due to typification error (Boyce and Wong 2008, 2009). Schottarum was recognised with S. sarikeense as type. However, the protologue was wrongly applied and later the authors published Schottariella as a replacement generic name for Schottarum, with Schottariella mirifica designated as type. Therefore, the name Schottarum can be used and here, a second species, Schismatoglottis josefii is transferred into Schottarum. The genus Schottarum is presented here with a key to all the genera in the tribe Schismatoglottideae.

Key to genera of Schismatoglottideae

1a. Modules monophyllous, congested in a distichous arrangement; petiolar sheath with a long-persistent, long ligular free portion.

Pichinia

1b. Modules mostly polyphyllous, if monophyllous then never distichous; petiolar sheath fully attached, persistent or marcescent; if free ligular then soon-marcescent......... 2

2a. Wings of petiolar sheath with long ligular free ligules. ....

$2 \mathrm{~b}$. Wings of petiolar sheath fully or almost fully attached to the petiole.

3a. Thecae of anther each with horn- or needle-like projections; ovules on basal placenta; seeds with a long, hooked micropylar appendage .....

Phymatarum

$3 b$. Thecae of anther without horn- or needle-like projections; ovules on parietal or basal placenta; seeds without a micropylar appendage

4a. Seeds never with a micropylar appendage ..............5

4b. Seeds often with a micropylar appendage................11

5a. Placentation basal .....

Schottarum

5b. Placentation parietal

Schismatoglottis

\section{[Multiflora Group]}

6a. Inflorescences on very slender peduncles, nodding at anthesis, peduncle at spathe insertion flexing $180^{\circ}$ from vertical axis; infructescences narrowly campanulate, nodding; plants of podzols.

Hestia

6b. Inflorescences erect to nodding at anthesis, if nodding, then plants massive pachycauls, and peduncle very stout; infructescences fusiform with a constricted orifice, if campanulate, then thick-walled and erect, never nodding; plants of various substrates but never on podzols ............ 7

7a. Shoot modules hapaxanthic [Calyptrata Group]

Schismatoglottis

7b. Shoot modules pleionanthic 8

8a. Petiole sheathing only at extreme base; each foliage leaf alternating with a cataphyll

\section{[Tecturata Group]} Schismatoglottis

$8 \mathrm{~b}$. Petiole usually sheathing for at least a third of its length (rarely less); foliage leaves not alternating with cataphylls ... 9

9a. Pistillate and staminate flower zones separated by a conspicuous partly naked somewhat swollen interstice; inflorescences erect; spathe limb semi-persistent and barely opening during anthesis and then clasping the spadix, falling with spent parts of the spadix; petiolar sheath wings usually (but not always) deciduous .....

Apoballis

9b. Pistillate and staminate flower zones not separated by a naked interstice; spathe not persistent or, if so, the inflorescence nodding; petiolar sheath wings persistent 10

10a. Small to medium plants, often with asperate petioles and sometime the whole plant coarsely hairy; inflorescence erect; spathe limb irregularly crumbling and breaking away at or after staminate anthesis ..............................Schismatoglottis [Asperata Group]

10b. Massive glabrous pachycauls; inflorescence nodding; spathe limb clasping the spadix and more-or-less marcescent after anthesis, finally falling with spent parts of spadix. Schismatoglottis [Corneri Group]

11a. Thecae of anther never with horn- or needle-like projections..... 12

11b. Thecae of anther each with a horn- or needle-like projection, although sometimes visible only after pistillate anthesis. 16

12a. Spadix free; spathe limb caducous during anthesis; infructescence on erect peduncle; lower spathe forming a splash-cup

12b. Spadix partially to almost completely adnate to spathe; spathe limb not caducous during anthesis; infructescence on declinate peduncle; lower spathe not forming a

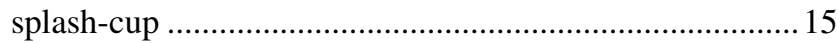

13a. Anther connective extended into a pronounced elongate beak ..................................... Piptospatha insignis

13b. Anther connective not so, or if elevated then shortly

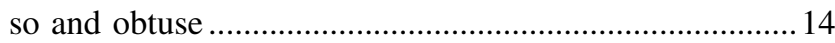


14a. Spathe white; leaf blade with conspicuously tessellate tertiary venation on both surfaces perakensis

Piptospatha

14b. Spathe not white; leaf blade without tessellate venation, or if present then only very faint and only abaxially Piptospatha pr. pte. (excl. Type)

15a. Staminate flowers mostly sterile with a narrow zone of fertile flowers exposed by the spathe opening; spathe persistent into fruiting, at fruit maturity swiftly drying, reflexing and opening basally by tearing at peduncle insertion to expose fruits but remaining distally convolute and while in this situation clasping the spadix; ovules basal; seeds with a blunt micropyle

Bakoa

15b. Staminate flowers all fertile; spathe persistent throughout the fruit dispersal; ovules parietal; seeds with a pronounced, hooked, micropylar appendage

Ooia

16a. Thecae with needle-like projection extending only after pistillate anthesis; projection tipped with a weakly peltate ovate-triangular flap; appendix composed of pistillodes

Schottariella

16b. Thecae with a horn- or needle-like projection present prior to pistillate anthesis; with the projection pointed and never associated with a terminal flap; appendix, where present, composed of staminodes.

17a. Sterile interstice of spadix with flattened scale-like motile staminodes; anthers not excavated...Bucephalandra

17b. Sterile interstice absent, or with truncate staminodes; anthers mostly with the top excavated .................. 18

18a. Staminate flowers each with two stamens; connective usually clearly excavated. 19

18b. Staminate flowers each with one stamen; connective not excavated, or salver-form.

19a. Stamen connective clearly and deeply excavated; thecae horns never longer than the stamen.........Aridarum pr. pte.

19b. Stamen connective umbonate; thecae horns longer than the stamen. Aridarum montanum

20a. Peduncle and inflorescence pendent; spathe limb hardly opening at anthesis; interstice staminodes horseshoe shaped, expanding laterally during anthesis; persistent lower spathe very slender funnel-form

Aridarum

\section{Rostratum Complex}

20b. Peduncle erect; and inflorescence erect to slightly nodding; spathe limb opening wide at anthesis; interstice staminodes never hose-shoe shaped, not expanding; persistent lower spathe broadly salverform.

Aridarum

\section{Burtii Complex}

Schottarum P. C. Boyce \& S. Y. Wong; P. C. Boyce \& S. Y. Wong, Bot. Stud. (Taipei) 49(4): 393 (2008). TypeSchottarum sarikeense (Bogner \& M. Hotta) P. C. Boyce \& S. Y. Wong Fig. 2.

Schottarum is defined by having basal placentation, 3-6 ovules, seeds without micropylar appendage, a spathe with a constriction, a narrowly campanuliform persistent lower spathe in fruiting, and a pistillate flower zone almost completely adnate to the spathe. Leaf blades are leathery, deep green adaxially, abaxially much paler and with pellucid primary and interprimary veins, which are almost not differentiated from each other, and petioles with long free ligules that long persist as dry tissue.

Obligate rheophytic small herb. Stem condensed. Leaves several together; petiole shorter than blade length, sometimes equal, slender, almost terete, adaxially canaliculate especially in distal part, sheathing only at extreme base, the wings extended into a very narrowly triangular ligular portion; blade leathery, very narrowly elliptic, adaxially glossy (not always) dark green, paler abaxially, the base cuneate, the apex acuminate; midrib abaxially prominent, adaxially flush with the blade to slightly impressed, with 5-6 pellucid primary lateral veins on each side, diverging at ca $45^{\circ}$; interprimary venation prominent adaxially, pellucid, fine and dense, barely differentiated from primary venation; tertiary venation obscure. Inflorescence solitary; peduncle shorter than petiole. Spathe slightly nodding (down-curved in lower part); lower spathe narrowly ovoid, slightly down-curved, green, differentiated from the limb by a constriction; limb white, caducous, more or less lanceolate, somewhat inflated over the spadix, thence narrowed into a beaked tip. Spadix subcylindric; pistillate zone adnate to the spathe; pistils subglobose; stigma sessile, discoid, papillate; interpistillar staminodes absent from among the pistils, confined to a row along the spathe/ spadix adnation, stipitate, weakly clavate, slightly exceeding the pistils; sterile interstice confined to about 2 irregular whorls of sterile stamens at the base of the staminate zone; staminate zone wider than the pistillate zone; stamens crowded, truncate, flat-topped, rather irregular in shape and size, ellipsoid to dumbbell-shaped from above, partially to completely connate into groups of 2-3; appendix bullet-shaped, basally isodiametric with top of staminate zone, distally tapering and finally narrowly obtuse; staminodes of appendix columnar, flat-topped, faintly impressed, often united to the top into curved or sinuous groups. Fruiting spathe narrowly urceolate. Few seeds, without micropylar appendage.

Distribution Malesia: endemic to Kanowit-Song-Ai drainages, Sarawak, and probably beyond to the Bentuang Karimum National Park in Kalimantan. The recognition of the genus gives added weight to the presence of a newly delimited phytochore (a specific spatial distributional region defined by the plants that uniquely occur within it) based on these areas. Two species.

Habitat Old secondary and fragments of primary lowland riparian evergreen moist forest on shales. Schottarum is rheophytic on vertical clay-loam riverbanks. 

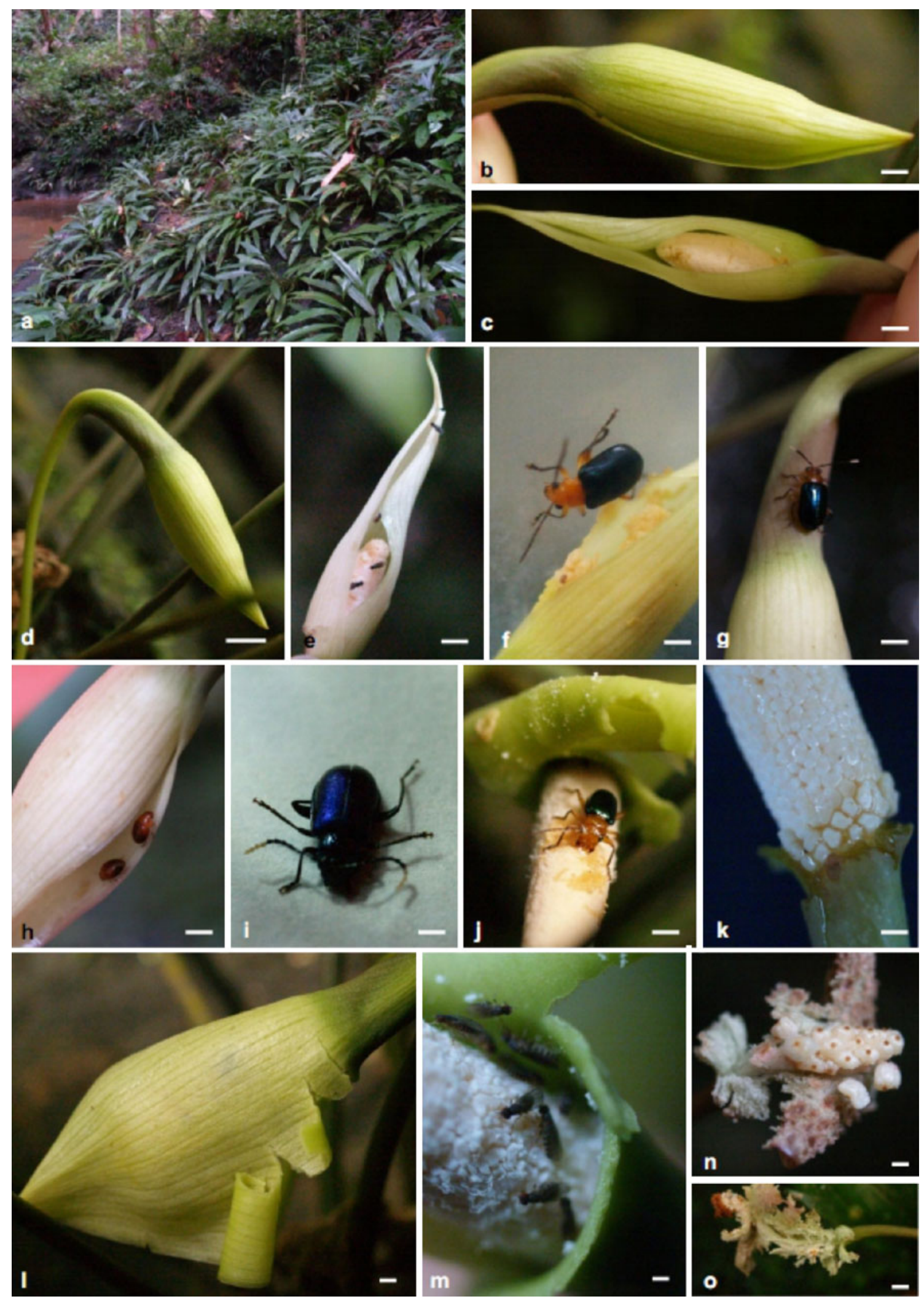

Etymology The generic name honours the Austrian botanist and plantsman Heinrich Wilhelm Schott (1794-1865), one of the founding fathers of Araceae systematics, the first monographer of the family, and the first botanist to make careful comparative studies of aroid inflorescences, flowers and fruits by which he 
4 Fig. 2 a Schottarum sarikeense (Bogner \& M. Hotta) P. C. Boyce \& S. Y. Wong. Habitat. b Gap opening along the spathe during early pistillate anthesis. c Gap open wider and remain open throughout the whole anthetic period. d Nodding inflorescence prior to pistillate anthesis. e, m Colocasiomyia, f, g Dercetina, h Nitidulid, i Altica cyanea, $\mathbf{j}$ Chaleonus, $\mathbf{k}$ Staminodes at interstice expanded during transition period, $\mathbf{l}$ abscission of still fresh spathe limb into several circumferential rings acroscopically from the middle part of spathe during staminate anthesis. $\mathbf{m}$ Pollen extruded in string and powder form. n Lower spathe split and reflexed to show the ripen fruit. o Infructescence empty. Scale bar $0.5 \mathrm{~cm}$

created the basis of Araceae taxonomy for succeeding generations.

Key to species of Schottarum

1a. Spadix adnate to the spathe on the dorsal side of the pistillate flower zone at its whole length; ovary more or less depressedglobose .....S. sarikeense

1b. Spadix adnate to the spathe on the dorsal side to half the length of the pistillate flower zone; ovary subglobose.......S. josefii

1. Schottarum sarikeense (Bogner \& M. Hotta) P. C. Boyce \& S. Y. Wong.

Basionym: Hottarum sarikeense Bogner \& M. Hotta, Bull. Mus. Natl. Hist. Nat., B, Adansonia 5 (1983) 27, Pl. 1-3; Mayo et al., Genera of Araceae (1997) 188, Pl. 51, F-J.-Type: Malaysia, Sarawak, Sarikei Division, near Sarikei, Sept. 1978, J. Bogner 1553 Cult. Botanischer Garten München (holotype: KYO; isotypes: K!, M!, P!, US!).

Synonym: Schismatoglottis sarikeensis (Bogner \& M. Hotta) A. Hay \& Bogner, Telopea 9(1): 100 (2000).

Rheophytic herb to ca $20 \mathrm{~cm}$ tall. Stem condensed, $0.5-0.8 \mathrm{~cm}$ diam. Leaves several together; petiole $6-12 \mathrm{~cm}$ long, slender, adaxially canaliculate especially in distal part, sheathing only at extreme base, the wings extended into a very narrowly triangular ligular portion 4-7 cm long, green tinged red, drying brown; blade very narrowly elliptic, $10-14 \mathrm{~cm}$ long $\times 1-2.5 \mathrm{~cm}$ wide, adaxially glossy dark green, paler abaxially, the base cuneate, the apex acuminate to caudate for $1.5-3 \mathrm{~cm}$; midrib abaxially prominent, adaxially flush with the lamina to slightly impressed, with 5-6 extremely fine (barely differentiated from secondary venation) primary lateral veins on each side, diverging at ca $45^{\circ}$; secondary venation faintly prominent adaxially, fine and dense; tertiary venation obscure. Inflorescence solitary; peduncle 7-8 cm long. Spathe slightly nodding (downcurved in lower part), 5-6 cm long; lower spathe narrowly ovoid, slightly down-curved, green, 1.5-2 cm long, differentiated from the limb by a constriction; limb white, caducous, more or less lanceolate, somewhat inflated over the spadix, thence narrowed into a beaked tip. Spadix subcylindric, 3-3.5 cm long; pistillate zone $1-1.2 \mathrm{~cm}$ long, wholly adnate to the spathe on the dorsal side, ca $3 \mathrm{~mm}$ diam.; pistils more or less depressed-globose, ca $1 \mathrm{~mm}$ diam.; stigma sessile, discoid, ca $0.4 \mathrm{~mm}$ diam., papillate; interpistillar staminodes absent from among the pistils, confined to a row along the spathe/spadix adnation, stipitate, weakly clavate, slightly exceeding the pistils; sterile interstice confined to about 2 irregular whorls of sterile stamens at the base of the staminate zone; staminate zone ca $1 \mathrm{~cm}$ long, wider than the pistillate zone, ca $0.5 \mathrm{~cm}$ diam.; stamens crowded, truncate, flat-topped, rather irregular in shape and size, ellipsoid to dumbbell-shaped from above, ca $0.5 \mathrm{~mm}$ across, partially to completely connate into groups of $2-3$; appendix bullet-shaped, basally isodiametric with top of staminate zone, distally tapering and finally narrowly obtuse, ca $0.5 \mathrm{~cm}$ long; staminodes of appendix columnar, flat-topped, faintly impressed, ca $0.5 \mathrm{~mm}$ diam., often united to the top into curved or sinuous groups. Fruiting spathe narrowly urceolate. Few seeds, without micropylar appendage.

Other specimens examined BORNEO: SARAWAK: Sri Aman Division: Lubok Antu, Batang Ai, Nanga Sumpa, Wong Enseluai, $01.11 \mathrm{~N}$ 112.04E, 6 April 2005, $P$. C. Boyce et al. AR-1133 (SAR); Lubok Antu, Batang Ai, Nanga Sumpa, Rumah Gumbang, Sungai Delok, 01.12N 112.03E, 24 May 2008, P. C. Boyce et al. AR-2366 (SAR); Lubok Antu, Batang Ai, Nanga Sumpa, Sungai Pedali, 01.11N 112.03E, 25 May 2008, P. C. Boyce et al. AR-2394 \& AR-2409 (SAR); Lubok Antu, Batang Ai, Nanga Sumpa, Wong Enseluai, 01.11N 112.03E, 26 May 2008. P. C. Boyce et al. AR-2418 (SAR); Betong Division: Roban, Sebangkoi, Taman Rekreasi Sebangkoi, 01.57N 111.26E, 5 Dec. 2005. P. C. Boyce et al. AR-1548 (SAR); Roban, Sebangkoi, Taman Rekreasi Sebangkoi, 01.57N 111.26E, 7-Feb. 2010, S. L. Low AR-3000, AR-3001, AR-3002 (SAR);; Sarikei Division: Sarikei, Sungai Lepong, 01.57N 111.30E, 8 Dec. 2005, P. C. Boyce, et al. AR-1605 (SAR); Maradong, Rumah Dakun ak Jenang, Sungai Matob, 01.52N 111.55E, 1 Sept. 2011, P. C. Boyce \& S. Y. Wong $A R$-3659 (SAR); Sungai Lepong, 01.57N 111.30E, 27 Dec. 2012, P. C. Boyce \& S. Y. Wong AR-4098 (SAR).

2. Schottarum josefii (A. Hay) P. C. Boyce, S. Y. Wong \& S. L. Low, comb. nov.

Basionym: Schismatoglottis josefii A. Hay, A. Hay \& Bogner, Telopea 9(1): 100 (2000) 90, Fig. 11-Type: Malaysia, Sarawak, Sarikei Division, Entabai, 3 Sep 1978, J. Bogner 1353 (holotype: M!).

Very small herb to $15 \mathrm{~cm}$ tall. Stem condensed, suberect, ca $3 \mathrm{~cm}$ long, ca $6 \mathrm{~mm}$ diam., pleionanthic. Leaves 5 together; petiole slender, to $7 \mathrm{~cm}$ long, shorter than the blade, sheathing only at the extreme base, but sheath extended into a tapering bicarinate free ligular portion to $3.2 \mathrm{~cm}$ long; blade narrowly lanceolate, to $11.5 \mathrm{~cm}$ 
Table 3 Type and number of insect visitors in Schottarum sarikeense

Twenty inflorescences were observed

\begin{tabular}{llllll}
\hline & Colocasiomyia & Dercetina & Chaleonus & Altica cyanea & Nitidulidae \\
\hline Total & 119 & 4 & 16 & 1 & 9 \\
$\%$ & 79.87 & 2.68 & 10.74 & 0.67 & 6.04 \\
Mean \pm SD & $5.95 \pm 12.56$ & $0.2 \pm 2.91$ & $0.8 \pm 1.94$ & $0.05 \pm 0.18$ & $0.45 \pm$ \\
Range (per inflorescence) & $1-21$ & $0-2$ & $0-4$ & $0-1$ & $0-2$ \\
\hline
\end{tabular}

long $\times 1.1 \mathrm{~cm}$ wide, the base cuneate, the apex indistinctly acuminate for $1.2 \mathrm{~cm}$ including a $2 \mathrm{~mm}$ cylindric mucro; midrib prominent adaxially and abaxially; primary lateral veins extremely fine, adaxially impressed, abaxially almost indistinguishable from secondary veins (hand lens required), 3 on each side of midrib, subopposite, diverging at ca $30^{\circ}$; secondary venation adaxially obscure, abaxially very fine and dense, arising from the midrib. Inflorescence solitary, subtended by lanceolate cataphylls to $3 \mathrm{~cm}$ long; peduncle much shorter than the petioles and not exceeding the cataphylls, $2 \mathrm{~cm}$ long. Spathe $2 \mathrm{~cm}$ long, green; lower spathe subcylindric, $5 \mathrm{~mm}$ long, differentiated from the limb by a very weak constriction; limb $1.5 \mathrm{~cm}$ long, somewhat inflated over the appendix of the spadix, then acuminate for $6 \mathrm{~mm}$, caducous. Spadix subcylindric; ca $1 \mathrm{~cm}$ long; pistillate zone slender, $4 \mathrm{~mm}$ long, half the length of the pistillate flower zone adnate to the spathe on the dorsal side; pistils crowded; ovary subglobose, ca $0.5 \mathrm{~mm}$ diam.; stigma sessile, about half the diameter of the ovary, button-like, very weakly 3-4-lobed, papillate; interpistillar staminodes confined to a single row along each side of the spathe/spadix adnation, stalked, flat-topped, about the same height as the pistils; sterile interstice ca $1 \mathrm{~mm}$ long, somewhat wider than the pistillate zone, 1-2 irregular whorls of centrally impressed sterile stamens; staminate zone $3 \mathrm{~mm}$ long $\times 1.7 \mathrm{~mm}$ thick; stamens crowded; anthers truncate, irregularly rectangular, ca $0.25 \mathrm{~mm}$ across, with the connective somewhat dilated and sometimes expanded on one side; thecae somewhat raised above the connective; appendix $5 \mathrm{~mm}$ long, ellipsoid-clavate, formed of flat-topped irregularly discoid staminodes ca $0.5 \mathrm{~mm}$ across. Fruit unknown.

Other specimens examined BORNEO: SARAWAK: Betong Division: Spaoh, Jalan Ulu Paku, Nanga Perum, 01.37N 111.35E, 16 Nov 2011, P. C. Boyce \& S. Y. Wong AR-3700 (SAR); Sri Aman Division: Lubok Antu, Batang Ai, Nanga Sumpa, Sungai Pedali, 01.11N 112.03E, 7 April 2005, P. C. Boyce, et al. AR-1157 (SAR).

Flowering mechanism, pollination strategy, fruitset, and seed dispersal of Schottarum sarikeense.

Schottarum sarikeense flowers diurnally, and so far this is unique in the tribe Schismatoglottideae where all other observed species flower at early dawn (Boyce, unpublished data). The mature inflorescence $(4.23 \mathrm{~cm}$ long $\times 0.65 \mathrm{~cm}$ wide) is held in nodding position (Fig. 2d). Prior to anthesis, the spathe limb loosened from the adpressed position. The anthesis of $S$. sarikeense began on the late afternoon and lasted for ca $26 \mathrm{~h}$. Pistillate anthesis commenced around 1,500 $\mathrm{h}$ with the inflation of spathe limb and two gaps (ca $1 \mathrm{~mm}$ wide) were formed separately near the tip and lower spathe. A mild esteric odour was emitted from the appendix, which lasted for the whole anthetic. The gap extended along the spathe margin within $20 \mathrm{~min}$ and spathe limb opened to a maximum width of ca $4 \mathrm{~mm}$ at the mid point, and the spadix was clearly visible (Fig. 2b, c). The spathe remained open throughout the anthesis. A gap between spathe and interstice (ca $1 \mathrm{~mm}$ diam.) allowed only Colocasiomyia (Diptera: Drosophilidae; ca $1.5 \mathrm{~mm}$ in long $\times$ ca $0.5 \mathrm{~mm}$ in wide; Fig. $2 \mathrm{e}, \mathrm{m})$ to enter into pistillate zone. The stigmas (each ca $1 \mathrm{~mm}$ in length $\times 1 \mathrm{~mm}$ in width) were receptive. The flies were observed to move freely, up and down the spadix. Dercetina (Coleoptera: Chrysomelidae), Chaleonus (Coleoptera: Chrysomelidae) (both type of insects, similar size, ca 6-7 mm long $\times 3-4 \mathrm{~mm}$ wide) and Nitidulid (Coleoptera: Nitidulidae; ca $2 \mathrm{~mm}$ long $\times$ ca $1.5 \mathrm{~mm}$ wide) were occasionally found present at the staminate zones and appendices during pistillate anthesis. Dercetina (Fig. 2f) and Chaleonus (Fig. 2e) predated on the appendices and spathe margins; and occasionally defecated in the inflorescences. Nitidulids were observed moving around although evidence of destruction was not found (Fig. 2h). Nitidulids were not found in any of inflorescences, which were bagged and therefore, it was confirmed that the nitidulids were attracted to the colour of the spathe instead to the floral scent released, which attracted Colocasiomyia, Dercetina and Chaleonus. Furthermore, another species of beetle, Altica cyanea (Chrysomelidae: Alticini) was occasionally found in the inflorescence of $S$. sarikeense (Fig. 2i). At ca $2,100 \mathrm{~h}$, pistillodes at interstice expanded to block the entrance into the pistillate zone and this marked the end of pistillate anthesis for $S$. sarikeense (Fig. 2k). Colocasiomyia shifted to the upper part of spadix prior to the closure of lower chamber (Fig. 2e).

On the second day at $1,430 \mathrm{~h}$, staminate anthesis started with the abscission of still fresh spathe limb into several circumferential rings acroscopically from middle part of spathe within an hour (Fig. 21). Shortly after, pollen was released in powder and long thread (Fig. $2 \mathrm{~m}$ ). After ca $2 \mathrm{~h}$ of staminate anthesis, Colocasiomyia, Dercetina, Chaleonus, and nitidulid left the inflorescence with pollen seen 
attached to their bodies. Colocasiomyia amounted up to $80 \%$ of the total insect visitors in $S$. sarikeense, with a range from 1 to 21 individuals per inflorescence (Table 3). The beetles did not access into the pistillate zone, therefore they were determined as the pollen robbers with Colocasiomyia suggested as the pollinators of S. sarikeense.

The staminate zone and appendix dried, and abscissed at ca 8-9 days post-anthesis, leaving with interstice's staminodes remaining. The percentage of fruitset for $S$. sarikeense was as high as $92.04 \%$. The mature infructescences split and reflexed to reveal the ripen fruits (Fig. $2 n-0$ ). On the following morning, fruits were dispersed by rainfalls and the uprising stream.

Acknowledgments This study was partially funded by the ITTO fellowship [Ref. No. 056/10A] to the first author. This is part of an ongoing research which is funded by the Ministry of Higher Education,
Malaysia by Grant vot: ERGS/01(02)/808/2011(03). The collaboration and support of the Sarawak Forestry Department are gratefully acknowledged for the permission to carry out the research under Research Permit No. NPW.907.4. (IV)-133 and Park Permit No. 99/2009.

\section{Appendix}

Taxonomic position, herbarium voucher number, collection locality, and GenBank accession number of the species included in the phylogenetic analysis of tribe Schismatoglottideae and Philonotieae[Taxa are arranged alphabetically following the taxonomic position of Mayo et al. (1997), Bogner and Hay (2000), Hay and Yuzammi (2000), and Wong et al. (2010)]. Taxonomic combinations in single quotation marks have not been made; generic placements in these instances are inferred.

Species, taxonomic position, collection locality, collectors, herbarium voucher no. and, GenBank accession no. (trnL-F, $m a t \mathrm{~K}, \operatorname{trn} \mathrm{H}-p s b \mathrm{~A}$, ITS) $-=$ not available

Aridarum borneense (M. Hotta) Bogner \& A. Hay, Aridarum section Aridarum, Sg. Bungen, Kubah National Park, Matang, Sarawak, 01³6 30.9"; $110^{\circ} 11^{\prime} 35.0^{\prime \prime}$, P. C. Boyce et al. Ar2123 (SAR), GQ220954, GQ220886, KC454019, JN544438; Aridarum caulescens M. Hotta, Aridarum section Caulescentia, Bukit Satiam, Bintulu, Sarawak, 02 ${ }^{\circ} 58^{\prime}$ 47.6"; $112^{\circ} 56^{\prime}$ 37.5" , P. C. Boyce \& J. Kisai Ar588 (SAR), KC454027, KC454002, KC454011, JN544428; Aridarum caulescens M. Hotta, Aridarum section Caulescentia, Melinau Gorge, Mulu Naltional Park, Nanga Medamit, Limbang, Sarawak, coordinates unobtainable, P. C. Boyce et al. Ar2311 (SAR), JN1774880, JN177490, KC454021, JN544440; Aridarum crassum S. Y. Wong \& P. C. Boyce, Aridarum section Aridarum, Gunung Gaharu, Pantu, Sri Aman, Sarawak, 0101' 19.5"; $110^{\circ} 52^{\prime}$ 52.8', P. C. Boyce \& J. Kisai Ar263 (SAR), GQ220957, GQ220889, KC454009, JN544426; Aridarum nicolsonii Bogner, Aridarum section Aridarum, Trail above Camp Permai, Camp Permai, Santubong, Kuching, Sarawak, 01 ${ }^{\circ} 45^{\prime} 49.0^{\prime \prime}$; $110^{\circ} 19^{\prime}$ 07.4", P. C. Boyce et al. Ar480 (SAR), JN177481, JN177491, KC454010, JN544427; Aridarum nicolsonii Bogner, Aridarum section Aridarum, Trail to Teluk Tajor, Bako National Park, Kuching, Sarawak, 01 ${ }^{\circ} 43^{\prime}$ 03.1'; $110^{\circ} 26^{\prime} 42.7^{\prime \prime}$, P. C. Boyce \& S. Y. Wong Ar2098 (SAR), GQ220958, GQ220890, KC454018, JN544437; Aridarum purseglovei (Furtado) M. Hotta, Aridarum section Caulescentia,

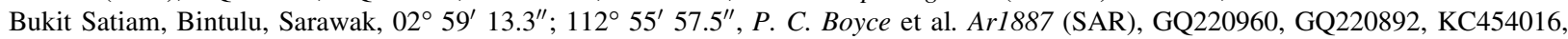
JN544435; Aridarum purseglovei (Furtado) M. Hotta, Aridarum section Aridarum, Sungai Likau, GT Plantations, Tatau, Bintulu, Sarawak, $02^{\circ} 43^{\prime}$ 53.6"'; $113^{\circ} 25^{\prime}$ 19.1" , P. C. Boyce et al. Ar3096 (SAR), JN177483, JN177493, KC454025, JN544444; Bucephalandra motleyana Schott, Bucephalandra, Gunung Gaharu, Pantu, Sri Aman, Sarawak, 01 ${ }^{\circ} 02^{\prime}$ 39.5'; $110^{\circ} 53^{\prime} 18.3^{\prime \prime}$, P. C. Boyce \& J. Kisai Ar252 (SAR), GQ220963, GQ220895, KC454008, JN544425; Bucephalandra motleyana Schott, Bucephalandra, Melinau Gorge, Mulu Naltional Park, Nanga Medamit, Limbang, Sarawak, coordinate unobtainable, P. C. Boyce et al. Ar2310 (SAR), KC454029, KC454004, KC454020, JN544439; Bucephalandra motleyana Schott, Bucephalandra, Lower slopes, Bukit Kelam, Sintang, Kalimantan Barat, Indonesia, 00 05' 30.1"; $111^{\circ} 39^{\prime}$ 03.3", P. C. Boyce \& S. Y. Wong Ar2537 (SAR), KC454030, KC454005, KC454023, JN544442; Hottarum truncatum (M. Hotta) Bogner \& Nicolson, Hottarum, Sungai Pandan Kecil, Trail behind Camp C, GT Plantations, Tatau, Bintulu, Sarawak, 02 ${ }^{\circ} 42^{\prime} 40.1^{\prime \prime}$; $113^{\circ} 20^{\prime} 37.9^{\prime \prime}$, P. C. Boyce et al. Ar3080 (SAR), JN177482, JN177492, KC454024, JN544443; Phymatarum borneense M. Hotta, Phymatarum, Belaga Road, Sebauh, Bintulu, Sarawak, 03 03' 34.3"; $113^{\circ} 42^{\prime} 16.4^{\prime \prime}$, P. C. Boyce et al. Arl442 (SAR), GQ220969, GQ220899, KC454014, JN544433; Phymatarum borneense M. Hotta, Phymatarum, Trail to Deer Cave, Mulu National Park, Mulu, Miri, Sarawak, 04 02' 23.8"'; $114^{\circ} 48^{\prime}$ 54.6", P. C. Boyce et al. Ar1931 (SAR), GQ220970, GQ220900, KC454017, JN544436; Philonotion americanum (A. M. E. Jonker \& Jonker) S. Y. Wong \& P. C. Boyce, Philonotion, French Guiana, J. Bogner, BOGNER 2911, GQ220978, GQ220908, JX962839, JN544445; Schismatoglottis'adoceta' S. Y. Wong, Nervosa Group, Road junction, km 10 Bakun- Bintulu- Miri, Belaga, Kapit, Sarawak, $02^{\circ} 50^{\prime}$ 51.7"; 114 01' 57.6", P. C. Boyce et al. Ar1408 (SAR), JX857132, JN570739, JX857150, JN544432; Schismatoglottis 'macrocardia' S. Y. Wong \& P. C. Boyce, Asperata Group, Bukit Satiam, Bintulu, Sarawak, $02^{\circ} 59^{\prime} 26.1^{\prime \prime} ; 112^{\circ} 55^{\prime}$ 54.4", P. C. Boyce \& J. Kisai Ar607 (SAR), JN177487, JN177497, JX962838, JN544429; Schismatoglottis 'petradoxa' S. Y. Wong \& P. C. Boyce, Multiflora Group, km 65 road to Camp Gahada, Rejang Wood Concession, Nanga Gaat, Kapit, Sarawak, $01^{\circ} 41^{\prime} 59.7^{\prime \prime} ; 113^{\circ} 31^{\prime}$ 13.7", P. C. Boyce et al. Ar920 (SAR), KC454028, KC454003, KC454012; JN544430; Schismatoglottis sp. A, Multiflora Group, Sg. Piat, Nanga Gaat, Kapit, Sarawak, 01 38 09.1"; $113^{\circ} 24^{\prime}$ 09.9", P. C. Boyce \& J. Kisai Ar114 (SAR), GQ221011, GQ220946, KC454006, JN544423; Schismatoglottis sp. B, Stream below Camp Gahada, Rejang Wood Concession, Nanga Gaat, Kapit, Sarawak, 01 41' 49.4"; $113^{\circ} 26^{\prime} 16.3^{\prime \prime}$, P. C. Boyce \& J. Kisai Ar135 (SAR), KC454026, KC454001, KC454007, JN544424; Schottarum josefii (A. Hay) P.

C. Boyce, S. Y. Wong \& S. L. Low, Schottarum, Sg. Pedali, Nanga Sumpa, Batang Ai, Lubok Antu, Sri Aman, Sarawak, 01 $11^{\prime} 58.9^{\prime \prime}$; $112^{\circ} 03^{\prime}$ 27.0", P. C. Boyce et al. Ar1157 (SAR), GQ221012, GQ220947, KC454013, JN544431; Schottarum sarikeense (Bogner \& M. Hotta) P. C. Boyce \& S. Y. Wong, Schottarum, Sg. Lepong, Sarikei, Sarawak, 01 $57^{\prime} 12.9^{\prime \prime} ; 111^{\circ} 30^{\prime} 34.9^{\prime \prime}$, P. C. Boyce et al. Ar1605 (SAR), JN177488, JN177498, KC454015, JN544434; Schottarum sarikeense (Bogner \& M. Hotta) P. C. Boyce \& S. Y. Wong, Schottarum,

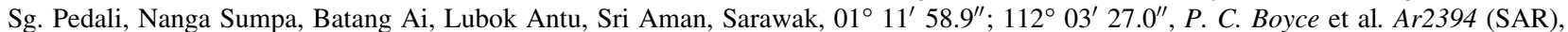
JN177489, JN177499, KC454022, JN544441. 


\section{References}

Akaike H (1974) A new look at the statistical model identification. System identification and time-series analysis. IEEE Trans Automat Control 19:716-723

Bogner J, Hay A (2000) Schismatoglottideae (Araceae) in Malesia 2: Aridarum, Bucephalandra, Phymatarum and Piptospatha. Telopea 9:179-222

Bogner J, Hotta M (1983) A new Hottarum (Araceae) from Sarawak. Bull Mus Natn His Nat B Adansonia 5:27-31

Boyce PC, Wong SY (2008) Studies on Schismatoglottideae (Araceae) of Borneo VII: Schottarum and Bakoa, two new genera from Sarawak, Malaysian Borneo. Bot Stud 49:393-404

Boyce PC, Wong SY (2009) Schottariella mirifica P.C. Boyce \& S.Y. Wong: a new name for Schottarum sarikeense (Araceae: Schismatoglottideae) (Araceae: Schismatoglottideae)—an erratum. Bot Stud 50:269-271

Cuénoud P, Savolainen V, Chatrou LW, Powell MW, Grayer RJ, Chase MW (2002) Molecular phylogenetic of Chryophyllales based on nuclear $18 \mathrm{~S}$ rDNA and plastid $r b c \mathrm{~L}$, atp $\mathrm{B}$, and $m a t \mathrm{~K}$ DNA sequences. Am J Bot 89:132-144

Cusimano N, Bogner J, Mayo SJ, Boyce PC, Wong SY, Hesse M, Hetterscheid WLA, Keating RC, French JC (2011) Relationships within the Araceae: comparison of morphological patterns with molecular phylogenies. Am J Bot 98:1-15

Doyle JJ, Doyle JL (1987) A rapid DNA isolation procedure for small quantities of fresh leaf tissue. Phytochem Bull 19:11-15

Farris JS, Källersjö M, Kluge AG, Bult C (1994) Testing significance of incongruence. Cladistics 10:315-319

Gravendeel B, Chase MW, Vogel EF, Roos MC, Mes THM, Bachmann R (2001) Molecular phylogeny of Coelogyne (Epidendroideae: Orchidaceae) based on plastid RFLPS, matK, and nuclear ribosomal ITS sequences: Evidence for polyphyly. Am J Bot 88:1915-1927

Hall TA (1999) BioEdit: a user-friendly biological sequence alignment editor and analysis program for Windows 95/98/NT. Nucl Acid S 41:95-98

Hay A, Yuzammi (2000) Schismatoglottideae (Araceae) in Malesia I-Schismatoglottis. Telopea 9:1-177

Huelsenbeck JP, Ronquist F (2001) MRBAYES: Bayesian inference of phylogenetic trees. Bioinformatics 17:754-755
Low SL, Wong SY, Jamliah J, Boyce PC (2011) Phylogenetic study of the Hottarum Group (Araceae: Schismatoglottideae) utilising the nuclear ITS region. Gardens' Bull Sing 63:237-243

Mayo SJ, Bogner J, Boyce PC (1997) The genera of Araceae. Royal Botanic Gardens, Kew

Posada D (2008) jModel test: phylogenetic model averaging. Mol Biol Evol 25:1253-1256

Sang T, Crawford DJ, Stuess TF (1997) Chloroplast DNA phylogeny, reticulate evolution, and biogeography of Paeonia (Paeoniaceae). Am J Bot 84:1120-1136

Stamatakis A, Hoover P, Rougemont J (2008) A rapid bootstrap algorithm for the RAxML Web-servers. Syst Biol 75:758-771

Steele KP, Vilgalys R (1994) Phylogenetic analysis of Polemoniaceae using nucleotide sequences of plastid gene matK. Syst Biol $19: 126-142$

Swofford DL (2002) PAUP*: phylogenetic analysis using parsimony (* and other methods), version 4.0 beta 10 . Sunderland: Sinauer Associates

Taberlet P, Gielly L, Pautou G, Bouvet J (1991) Universal primers for amplification of three non-coding regions of chloroplast DNA. Plant Mol Biol 17:1105-1109

Tate JA, Simpson BB (2003) Paraphyly of Tarasa (Malvaceae) and diverse origins of the polyploid species. Syst Bot 28:723-737

Ting APJ, Wong SY, Jamliah J, Boyce PC (2012) Phylogenetic study of Schismatoglottis Nervosa Complex (Araceae: Schismatoglottideae). Gardens' Bull Sing 64:211-219

White TJ, Bruns T, Lee S, Taylor J (1990) Amplification and direct sequencing of fungal ribosomal RNA genes for phylogenetics. In: Innia M, Gelfand DH, Sninsky JJ, White TJ (eds) PCR protocols. Academic Press, San Diego, pp 315-322

Wong SY (2013) Rheophytism in Bornean Schismatoglottideae (Araceae). Syst Bot 38:32-45

Wong SY, Boyce PC (2010) Studies on Schismatoglottideae (Araceae) of Borneo IX: a new genus, Hestia, and resurrection of Apoballis. Bot Stud 51:249-255

Wong SY, Boyce PC, Othman AS, Leaw CP (2010) Molecular phylogeny of tribe Schimatoglottidae based on two plastid markers and recognition of a new tribe, Philonotieae, from the neotropics. Taxon 59:117-124 